\title{
Development, feasibility and performance of a health risk appraisal questionnaire for older persons
}

\author{
Andreas E Stuck*1,2, Kalpa Kharicha3 ${ }^{3}$, Ulrike Dapp ${ }^{4}$, Jennifer Anders4, \\ Wolfgang von Renteln-Kruse ${ }^{4}$, Hans Peter Meier-Baumgartner ${ }^{4}$, \\ Danielle Harari ${ }^{5}$, Cameron G Swift ${ }^{6}$, Katja Ivanova ${ }^{1}$, Matthias Egger ${ }^{7}$, \\ Gerhard Gillmann ${ }^{7}$, Jerilyn Higa ${ }^{8}$, John C Beck ${ }^{9}$ and Steve Iliffe ${ }^{3}$
}

\begin{abstract}
Address: ${ }^{1}$ Department of Geriatrics, University of Bern, Spital Bern-Ziegler, Morillonstrasse 75-91, CH-3001 Bern, Switzerland, ${ }^{2}$ Division of Geriatrics, Department of General Internal Medicine, Insel University of Bern Hospital, CH-3010 Bern, Switzerland, ${ }^{3}$ Department of Primary Care and Population Sciences, University College London, Hampstead Campus, Rowland Hill Street, London NW3 2PF, UK, ${ }^{4}$ Albertinen-Haus Geriatrics Centre, University of Hamburg, Sellhopsweg 18-22, D-22459 Hamburg, Germany, ${ }^{5}$ Department of Ageing and Health, Guys and St Thomas' NHS Foundation Trust, 9th Floor North Wing, St Thomas' Hospital, Lambeth Palace Road, London SE1 7EH, UK, ${ }^{6}$ Department of Health Care of the Elderly, Kings College London, Clinical Age Research Unit, King's College Hospital, Bessemer Road, London SE5 9PJ, UK, ${ }^{7}$ Department of Social and Preventive Medicine, University of Bern, Finkenhubelweg 11, CH-3012 Bern, Switzerland, ${ }^{8}$ Department of Emergency Medicine, University of California, Los Angeles, California, USA and 'School of Medicine, University of California, Los Angeles, 10833 Le Conte Ave. $32-$ 144, Los Angeles CA-90024-1687, USA
\end{abstract}

Email: Andreas E Stuck* - andreas.stuck@bluewin.ch; Kalpa Kharicha - k.kharicha@pcps.ucl.ac.uk; Ulrike Dapp - ulrike.dapp@albertinen.de; Jennifer Anders - Jenny.Anders@albertinen.de; Wolfgang von Renteln-Kruse - w.renteln-kruse@albertinen.de; Hans Peter MeierBaumgartner - w.renteln-kruse@albertinen.de; Danielle Harari - danielle.harari@kcl.ac.uk; Cameron G Swift - cameron.swift@kcl.ac.uk; Katja Ivanova - Katja.Ivanova@spitalbern.ch; Matthias Egger - egger@ispm.unibe.ch; Gerhard Gillmann - gillmann@ispm.unibe.ch; Jerilyn Higa - jhiga@mednet.ucla.edu; John C Beck - egebjcb@ucla.edu; Steve Iliffe - s.iliffe@pcps.ucl.ac.uk

* Corresponding author

Published: II January 2007

BMC Medical Research Methodology 2007, 7:1 doi:10.1186/147/-2288-7-1
Received: 23 September 2006

Accepted: 1 I January 2007

This article is available from: http://www.biomedcentral.com/I47|-2288/7/I

(C) 2007 Stuck et al; licensee BioMed Central Ltd.

This is an Open Access article distributed under the terms of the Creative Commons Attribution License (http://creativecommons.org/licenses/by/2.0), which permits unrestricted use, distribution, and reproduction in any medium, provided the original work is properly cited.

\begin{abstract}
Background: Health risk appraisal is a promising method for health promotion and prevention in older persons. The Health Risk Appraisal for the Elderly (HRA-E) developed in the U.S. has unique features but has not been tested outside the United States.

Methods: Based on the original HRA-E, we developed a scientifically updated and regionally adapted multilingual Health Risk Appraisal for Older Persons (HRA-O) instrument consisting of a self-administered questionnaire and software-generated feed-back reports. We evaluated the practicability and performance of the questionnaire in non-disabled community-dwelling older persons in London (U.K.) ( $N=1090)$, Hamburg (Germany) $(\mathrm{N}=804)$, and Solothurn (Switzerland) $(\mathrm{N}=748)$ in a sub-sample of an international randomised controlled study.

Results: Over eighty percent of invited older persons returned the self-administered HRA-O questionnaire. Fair or poor selfperceived health status and older age were correlated with higher rates of non-return of the questionnaire. Older participants and those with lower educational levels reported more difficulty in completing the HRA-O questionnaire as compared to younger and higher educated persons. However, even among older participants and those with low educational level, more than $80 \%$ rated the questionnaire as easy to complete. Prevalence rates of risks for functional decline or problems were between $2 \%$ and $91 \%$ for the 19 HRA-O domains. Participants' intention to change health behaviour suggested that for some risk factors participants were in a pre-contemplation phase, having no short- or medium-term plans for change. Many participants perceived their health behaviour or preventative care uptake as optimal, despite indications of deficits according to the HRA-O based evaluation.

Conclusion: The HRA-O questionnaire was highly accepted by a broad range of community-dwelling non-disabled persons. It identified a high number of risks and problems, and provided information on participants' intention to change health behaviour.
\end{abstract}




\section{Background}

There is a growing interest in health risk appraisal (HRA) for use in older persons. HRA instruments typically consist of a questionnaire and an algorithm for generating feedback reports to participants and health care providers. Controlled studies support that HRA combined with supplemental counselling by a physician, health educator, or other health professional is a potentially cost-effective method of health promotion and prevention for older persons [1]. Providers, organisations or researchers interested in a HRA can now choose among multiple HRA instruments that have been developed for use in older persons [1].

There are multiple differences between available HRA instruments for use in older persons. The HRA-E (HRA for the Elderly) questionnaire developed by a University of California faculty group has several distinguishing features [1,2]: (1) its main purpose is to identify risk factors for functional decline; this contrasts with other HRA instruments which focus on risk factors for mortality or address selected health behaviour and preventative care issues alone; (2) unlike other HRA instruments, it is based on scientific evidence for the selection of risk factor domains and instruments to measure these domains, and for the definition of the recommendations in the feedback [1]; (3) unlike most other HRA questionnaires for older persons (with the exception of the YOU FIRST Senior Health Assessment [1]), it identifies intention and barriers to changing health behaviours which can be used to enhance tailoring of participant feed-back ; and (4) it includes a computerised algorithm to generate feed-back to both older persons and general practitioners or other health professionals (see Figure 1), in contrast with conventional HRA instruments which do not specifically address primary care practitioners.

However, despite these advantages, there are factors limiting the use of the HRA-E in Europe: first it had not been developed for use in a multilingual environment, second its feasibility and performance had not been tested outside the North American environment, and third, the HRA-E is outdated because new scientific evidence has accumulated since its development in 1997.

We decided to revise and update the original HRA-E and to name this new version "Health Risk Appraisal for Older Persons" (HRA-O) [3]. The stepwise development from HRA-E to HRA-O instrument versions 1 to 4 is described in the following paragraphs, and depicted in Figure 2.

\section{Development and testing of HRA-E}

The original HRA-E was used as a basis for the subsequent development of HRA-O versions. After a multi-step development process including a systematic literature review, expert input, as well as multiple focus group and pilot testing activities, a first version of the HRA-E was developed. It consisted of a self-administered questionnaire (for the 17 included domains, see Table 1), a software program for generating an individualised feed-back report to the older participant and a summary report for the health care professional [2]. This first version was tested in three samples of older Americans: (1) a large medical group practice with links to Health Maintenance Organization (HMO) plans, (2) a national sample of American Association of Retired Persons (AARP) members, and (3) a senior centre (total $N=1924$ ) [2]. A second version of the HRA-E was generated based on this experience.

\section{Scientific update of HRA-E}

The first step involved a scientific update of the HRA-E. First, based on a systematic literature search on risk factors for functional status decline in older persons [4], potential new domains for inclusion in the updated questionnaire were identified. This review was presented to an international Expert Panel (from Denmark, Germany, Netherlands, Switzerland, U.K., USA) in the fields of epidemiology, geriatrics, sociology and nursing. We used a consensus panel process adapted to a multilingual group of experts. They evaluated new potential domains based on the four criteria listed below, which had previously been used for the development of the original HRAE instrument:

(1) magnitude of effect and potential impact on functional impairment;

(2) validity and generalisability of results;

(3) potential for risk reduction;

(4) feasibility of assessment.

In a second step, the same Expert Panel selected instruments to measure new potential domains, and decided whether existing instruments in the original HRA-E questionnaire had to be replaced. A list of instruments to be considered was developed for each domain of the updated questionnaire, in conjunction with information from the current literature informing the experts about the validity and reliability of each instrument for use in community-dwelling older people. The following criteria for selecting the instruments or evaluating the inclusion of existing instruments were used:

(1) reliability;

(2) validity;

(3) feasibility; and 


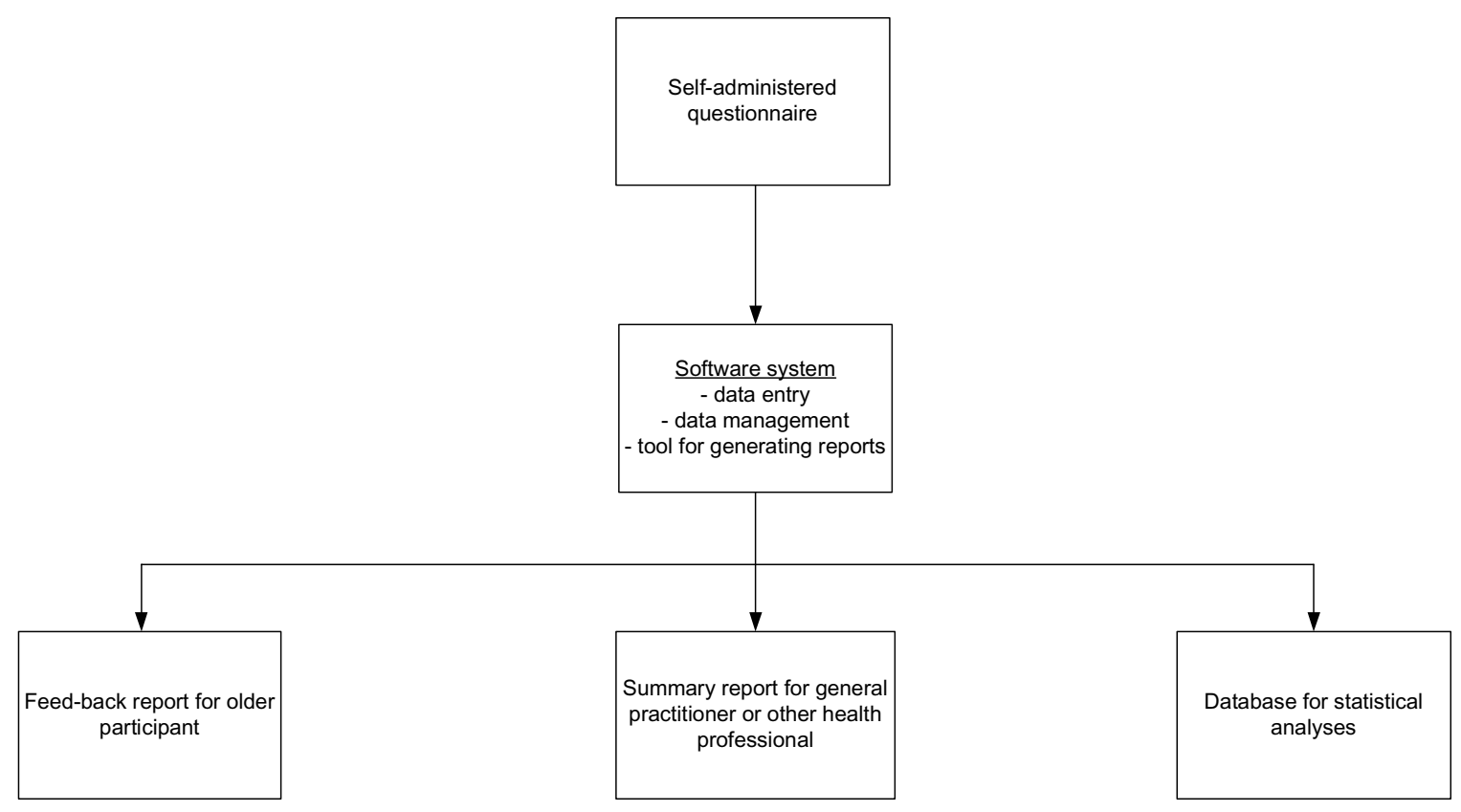

\section{Figure I}

Common components of Health Risk Appraisal for the Elderly (HRA-E) and of all versions of the Health Risk Appraisal for Older Persons (HRA-O)

(4) use of the instrument in other large databases of older persons.

\section{Development of HRA-O version I (HRA-O-I)}

Based on recommendations of the Expert Panel, specific questionnaires for two domains (on fruit/fibre intake and vision function, details in Table 1 ) were added to the new HRA-O-1 questionnaire. In addition, selected improvements were made for individual questionnaire items and recommendations in the feed-back statements.

In a next step, the questionnaire and text for the participant and provider feed-back reports were translated into the German language by a professional translator, and then translated back to the English language by a second translator who was blinded to the original version. The back-translation was compared with the original version, and discrepancies were resolved by a third independent translator. Based on this version intended for use in Ger- many, we developed a Switzerland German version by adapting language and grammar. Also, based on the American English version, a separate English version for use in the U.K. was developed, following changes to the language, grammar and style. These translations required a redesign of the original HRA-E to accommodate multiple language versions. This involved a revision of the questionnaire data entry system and of the software system generating the feed-back reports. The newly generated HRA-O-version-1 (HRA-O-1) was alpha tested by evaluating the functionality and content of data entry and report generation.

Based on this HRA-O-1, focus group meetings with older persons and general practitioners, and pilot tests in small groups of older persons in Switzerland, Germany, and the U.K., were conducted. The questionnaire was then regionally adapted without changing the content of the questions. For example, units for reporting weight (e.g., stones, 


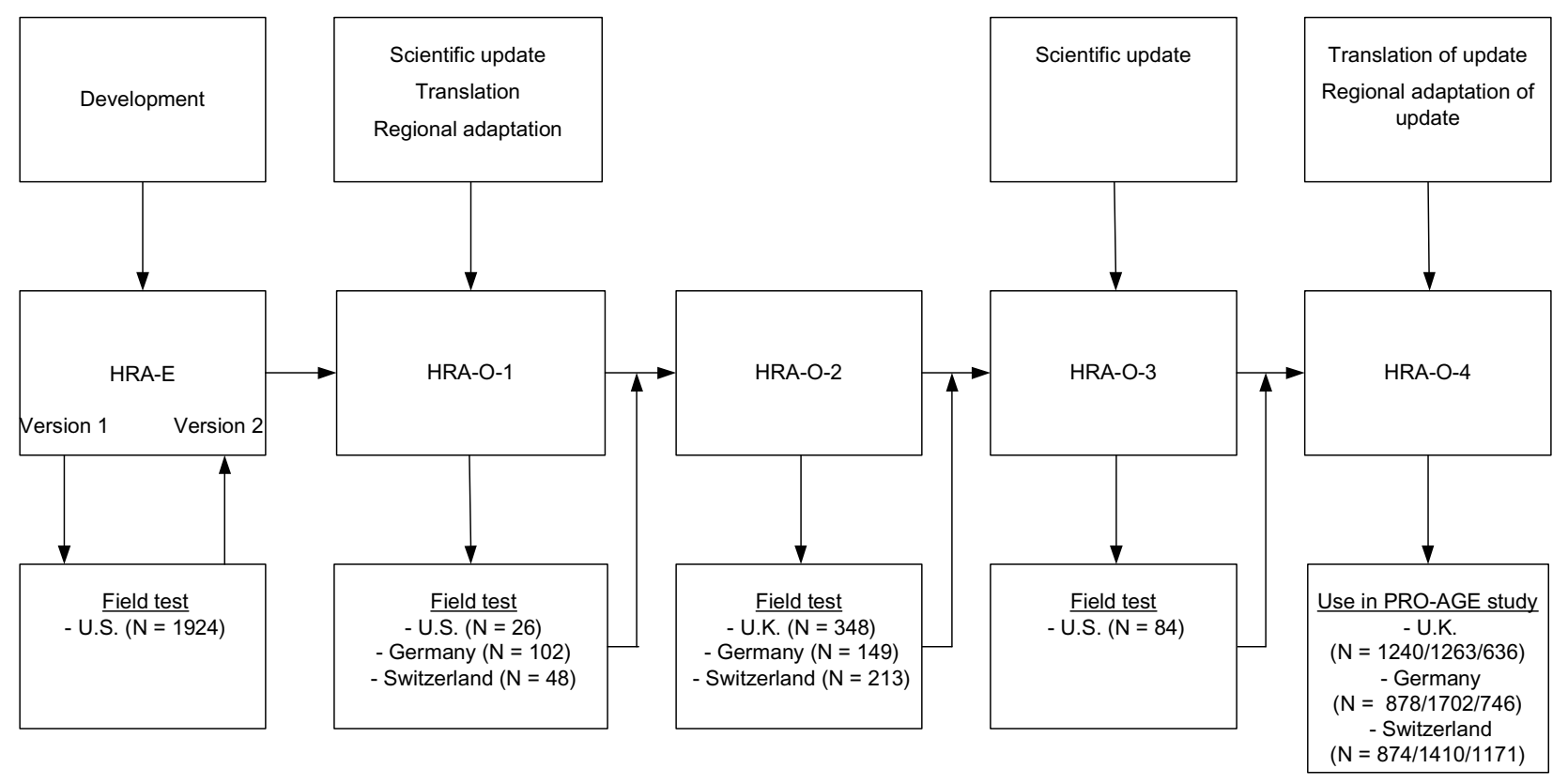

\section{Figure 2}

Development stages from the Health Risk Appraisal for the Elderly (HRA-E) to the Health Risk Appraisal for Older Persons version 4 (HRA-O)

kilograms) or examples of food items with a high fat content (e.g. hot dogs in U.K., and "Bratwurst" in Switzerland) were added as needed. The feed-back statements for the four language versions (American English, U.K. English, Germany German, and Switzerland German) were adapted to incorporate regional variations including postal addresses, referrals to health providers, and access or payment for preventative care services.

\section{Testing of HRA-O-I}

A field test in 26 community-dwelling older persons in the US evaluated the functionality and acceptance of HRA-O-1. In addition, we also conducted a study for evaluating the reliability of instruments included in the HRAO-1 questionnaire (Table 1) in three samples of community-dwelling persons aged 75 years and older in Hamburg (Germany) $(\mathrm{N}=51)$, Ulm (Germany) $(\mathrm{N}=51)$ and Bern (Switzerland) $(\mathrm{N}=48)$ [5]. In a first sub-sample of
100 persons, the test-retest reliability of individual questionnaires included in HRA-O-1 (Table 1) and of specific questionnaires on oral health and pain (two domains that we considered adding to the HRA-O-1 based on the Expert Panel recommendations) [6]. Test-retest reliability was good to excellent, as measured by Cohen's Kappa $(0.64 \leq$ $\kappa \leq 0.89$ ) [7], with the following exceptions. For three domains (pain, preventative care, and falls), Cohen's Kappa was $<0.6$. In a different sub-sample of 50 persons, the validity of the specific questionnaires included in the HRA-O-1 questionnaire was determined by comparing self-administered with interviewer-administered answers to the questionnaires [7]. Cohen's Kappa revealed good to excellent validity in most domains with values ranging between 0.69 and 1.0. Values were below 0.69 for questionnaires assessing physical activity, oral health, and basic activities of daily living. Low Kappa values could be explained by suboptimal presentation of the questions in 
Table I: Sources of Health Risk Appraisal for the Elderly (HRA-E) and Health Risk Appraisal for Older Persons (HRA-O) questionnaire

\begin{tabular}{|c|c|c|}
\hline Domain & Definition of problem risk & Description of questions (questionnaire item source) \\
\hline Accident prevention & Driving without using seat belt & Use of seatbelt [26] \\
\hline Alcohol use & $\begin{array}{l}\text { Possible hazardous alcohol use (based on age- and } \\
\text { gender-specific limits of quantity and frequency of self- } \\
\text { reported alcohol use) }\end{array}$ & The WHO Alcohol Use Disorders Identification Test [15] \\
\hline \multirow[t]{2}{*}{ Falls } & History of repeated falls in previous 12 months & Study of Osteoporotic Fractures Research Group Survey [20] \\
\hline & $\begin{array}{l}\text { Self-reported limitation of activities due to fear of } \\
\text { falling }\end{array}$ & Fear of falling [32] \\
\hline \multirow[t]{4}{*}{ Functional status } & Difficulty/need for human assistance in $\geq I \quad B A D L$ item & Basic activities of daily living (BADL) [19] \\
\hline & Difficulty/need for human assistance in $\geq 2$ IADL items & Instrumental activities of daily living (IADL) [22] \\
\hline & Changed kind of activity & Preclinical mobility disability $[13]^{*}$ \\
\hline & Decreased frequency of activity & \\
\hline Health status & Moderate or fair self-perceived health status & Self-perceived health status [18] \\
\hline \multirow[t]{2}{*}{ Hearing } & Impaired hearing & Hearing Handicap Inventory for the Elderly [23] \\
\hline & No hearing check-up in previous year & History of hearing examination [33] \\
\hline Incontinence & Urinary incontinence on $>5$ days during the last year & $\begin{array}{l}\text { Urinary incontinence (Medical, Epidemiological and Social Aspects } \\
\text { of Aging Project Questionnaire) [17] }\end{array}$ \\
\hline \multirow[t]{4}{*}{ Medication use } & Use of $\geq 4$ medications & Use of medications [2] \\
\hline & Use of long-acting benzodiazepine or amitriptyline & Inappropriate medication use $[14] *$ \\
\hline & Medication side effect & Medication side effects [35] \\
\hline & Difficulties with medication compliance & Medication compliance [2] \\
\hline Medical History & Presence of chronic condition(s) & Chronic conditions [18] \\
\hline Memory & Memory problems & Memory Self Report [28] \\
\hline Mood & Depressive mood & 5-item Mental Health Inventory Screening Test [29] \\
\hline \multirow[t]{6}{*}{ Nutrition } & Consumption of $>2$ high fat food items per day & Cholesterol Reduction in Seniors Program Fat Food Screening \\
\hline & & Questionnaire [3I] \\
\hline & Consumption of $<5$ fruit/fibre items per day & Cholesterol Reduction in Seniors Program Plant Food Screening \\
\hline & & Questionnaire $[3 I]^{*}$ \\
\hline & Motivation for change in fat intake/fruit intake & Transtheoretical model of behaviour change $[2,21,27]$ \\
\hline & Body mass index $<20$ or $\geq 27$; loss of weight & Self-reported height and weight (body mass index), weight change \\
\hline \multirow[t]{2}{*}{ Oral Health* } & Oral health problem & Geriatric oral health assessment index [ $\mathrm{II}]^{*}$ \\
\hline & No dental check in previous year & History of dental care [33] \\
\hline Pain* & Presence of moderate to severe pain & Geriatric Pain Measure [12]* \\
\hline \multirow[t]{2}{*}{ Physical activity } & $\begin{array}{l}\text { Less than } 5 \text { times/week moderate or strenuous } \\
\text { activity }\end{array}$ & Physical Activity Scale for the Elderly [34] \\
\hline & Motivation for behaviour change & Transtheoretical model of behaviour change $[2,21,27]$ \\
\hline \multirow[t]{10}{*}{ Preventative care } & No blood pressure control in previous year & History of blood pressure measurement [33] \\
\hline & Elevated self-reported blood pressure & Self-reported blood pressure \\
\hline & No mammography in previous 2 years & History of breast cancer screening [33] \\
\hline & No cervical smear in previous 3 years & History of cervical smear [33] \\
\hline & No cholesterol measurement in previous 5 years & History of cholesterol measurement [33] \\
\hline & Elevated self-reported cholesterol & Self-reported cholesterol level \\
\hline & No faecal occult blood test in previous year & History of colon cancer screening [33] \\
\hline & No blood glucose measurement in previous 3 years & History of diabetes screening [33] \\
\hline & No influenza vaccination in previous year & History of influenza immunisation [33] \\
\hline & No pneumococcal vaccination (ever) & History of pneumococcal immunisation [33] \\
\hline \multirow[t]{5}{*}{ Social factors } & Low level of emotional support & Medical Outcomes Study Social Support Survey [29] \\
\hline & High risk of social isolation & Lubben Social Network Scale [24] \\
\hline & Marginal family ties & Subscale Lubben Social Network Scale [24] \\
\hline & Marginal friendship ties & Lubben Social Network Scale [24] \\
\hline & No participation in groups & Single-item question [16] \\
\hline \multirow[t]{2}{*}{ Tobacco use } & Current tobacco use & $\begin{array}{l}\text { Tobacco use (Partners in Prevention Tobacco Use Questionnaire) } \\
\text { [2] }\end{array}$ \\
\hline & Motivation for behaviour change & Transtheoretical model of behaviour change $[2,21,27]$ \\
\hline \multirow[t]{2}{*}{ Vision } & Problem in $\geq$ I vision sub-domain & Visual Functioning Questionnaire [25]* \\
\hline & No vision check-up in previous year & History of vision examination [33] \\
\hline
\end{tabular}

In addition, the questionnaire includes socio-demographics survey items (age, gender, education, professional activity, living arrangement) and a survey for participant feed-back to the questionnaire. Items marked with an asterisk $(*)$ were added to the HRA-O questionnaires and are NOT included in the HRA-E. 
the self-administered questionnaire, and consequently, introductory statements, wording of these questions and graphical presentation of items were improved.

\section{Testing of HRA-O-version-2 (HRA-O-2)}

Based on the testing of HRA-O-1, a revised version HRA$\mathrm{O}-2$ was developed. The feasibility of this updated version was then tested in three selected samples of persons aged 65 years and older in three European countries (U.K.: urban-based general practitioner lists in London, $\mathrm{N}=348$; Germany: occupants of sheltered housing facilities in Hamburg, N = 149; Switzerland: community-based lists in rural/suburban area in the Cantons of Solothurn and Bern, $N=213$ ) [8]. The majority of people judged the questionnaire as easy to comprehend (U.K., 81.4\%; Germany, 93.1\%; Switzerland, 97.2\%) and to complete (83.2\%, 91.4\%, and 95.8\%, respectively). Feed-back from older persons to the participant reports was systematically evaluated [9].

We decided to further test the validity of self-reported information on preventative care use captured by HRA-O2. For this purpose, in the Swiss sub-sample $(\mathrm{N}=213)$, self-reported data of preventative care were compared with medical record based information obtained from general practitioners. Agreement between the two data sources was good to excellent with agreement rates eighty percent or more for the comparison between self-reported and record-based information for the individual measures of preventative care [10].

\section{Development of HRA-O-version-3 (HRA-O-3)}

Based on the original recommendations of the Expert Panel, two new domains were added to the revised HRAO-3 and measured using the following tools: (1) oral health: the Geriatric Oral Health Assessment Index (GOHAI) was added to assess the impact of oral conditions on physical and psychosocial functions [11] and (2) pain: the multidimensional Geriatric Pain Measure was selected to evaluate the experience and intensity of pain, the impact of pain on function and on social network [12]. Instruments were updated for two domains already included in previous HRA-O versions: (1) inappropriate medication use: we added questions on inappropriate medications, and selected from drugs with potentially severe side effects, the two categories that had the highest prevalence of use in a community-based sample of older persons [13]; (2) preclinical functional decline: a measure of preclinical functional decline was added to identify people early in the trajectory of functional status decline [14]. In addition, information contained in the feed-back reports was updated.

\section{Testing of HRA-O-3}

In order to test the functionality and feasibility of the updated HRA-O-3, a field test of the American English version was conducted in conjunction with the Center for Healthy Aging in Santa Monica, CA, U.S.A. Overall, 84 community-dwelling older persons completed the new HRA-O-3 questionnaires, received feed-back reports, and were asked to provide feed-back on the HRA-O-3. Results confirmed functionality and acceptability, and only minimal remaining areas of improvement were found at this stage. Furthermore persons who recalled the earlier field tests with the original HRA-E instrument confirmed that updates had resulted in improvement related to ease of administration and completeness of contents.

\section{Development and description of HRA-O-version-4 (HRA- 0-4)}

Translations and back-translations of newly added components, as well as regional adaptations were made. Based on the testing of HRA-O-3 in the U.S. setting, necessary revisions and adaptations were implemented. As a result, HRA-O-4 was produced in an American English, U.K. English, Germany German, and Switzerland German version (for components, see Figure 1). The U.K. English version of this version 4 of HRA-O questionnaire is enclosed [see Additional file 1]. The 19 domains included in the HRAO-4 questionnaire are listed in Table 1[11-35].

The generation of feed-back reports to older participants and health care providers is based on a computerised system, including a screen-guided system for manual data entry, and an automated analysis of the entered data. From the entered data, a software system generates summary or risk scores and corresponding detailed written feed-back on identified risks to the older person. The report summarises the suspected problem (while always emphasising that this information is based on self-report) and generates feedback by selecting and arranging words and sentences from more than 1000 possible feedback algorithms. Feed-back reports were developed using current scientific evidence related to health promotion, risk factor modification, and problem management. The summary feed-back report to the health care provider is arranged in the format of a check-list on one double sided page. The older person's report (approximately 32 pages) is personalised and contains both general information on each domain as well as individualised specific recommendations derived from the questionnaire analysis. Crosslinks were made between domains, for example by taking into account level of physical activity and body mass index when giving recommendations to an older person reporting high blood pressure management. Participants' intention to change health behaviour or self reported reasons for not changing behaviour was taken into account. 
In addition, feed-back reports to older participants also included sources of additional information.

\section{Goals of this study}

The goal of this paper is to evaluate the feasibility and performance of the newly developed HRA-O questionnaire with base-line data from an international randomised study, the PRO-AGE study (PRevention in Older people Assessment in GEneralists' practices) [3]. To evaluate its feasibility, we analysed response rates and feed-back from older persons, including subgroups of older persons in whom use of a self-administered questionnaire is often queried: those with a low level of education and the very old. To evaluate the performance of the HRA-O questionnaire, we determined prevalence rates of identified risks and problems and participants' intention to change health behaviour as well as self-perceived barriers to change.

\section{Methods}

\section{Study participants}

Data presented in this paper are from a randomised controlled study, the PRO-AGE study (London, U.K.; Hamburg, Germany; and Solothurn, Switzerland). In this study, non-disabled community-dwelling older persons were recruited from primary care and randomised to intervention and control groups [3]. After randomisation, all subjects allocated to the intervention group were sent the HRA-O questionnaire. This study examined the effects of the HRA-O linked with a site-specific reinforcement (i.e. supplemental counselling by a physician, health educator, or other health professional) on self reported health behaviour and use of preventative care. The ethical approval of the PRO-AGE project was from the Brent Medical Ethics Committee and King's College Hospital Research Ethics Committee (London), the Ethics Committee of the Ärztekammer Hamburg (Hamburg) and the Kantonale Ethikkommission Solothurn (EKO 0023) (Solothurn).

\section{Data collection}

Prior to randomisation, all study participants completed a screening Pra-questionnaire (Probability of repeated admissions questionnaire) [36], providing information on selected base-line characteristics of study participants. Based on this questionnaire, a Pra risk score [36] was calculated to define a priori risk strata in the randomised controlled study.

Older persons were posted the HRA-O questionnaire and asked to return the completed questionnaire to their general practitioners. For budgetary reasons, no reminders were sent to older persons who did not return the HRA-O questionnaire. The HRA-O questionnaire contained the items listed in Table 1 plus, at the end, a brief survey on participant feed-back to the questionnaire.

\section{Statistical analyses}

Analyses were conducted according to an a priori analytic plan. Base-line characteristics of persons who returned the HRA-O questionnaire ("responders") were compared with those of non-responding persons ("non-responders") using available pre-randomisation data. P-values for differences in base-line characteristics were derived from multivariable logistic regression analyses with a covariate pool consisting of the individual base-line items. P-values for differences in the Pra score between responders and non-responders were derived from t-tests.

Feed-back to the HRA-O questionnaire was compared between participants with higher and lower educational level, and between participants older and younger than 75 years. Categorical and binary outcome data are analysed using Fisher's exact tests, continuous outcome data are compared using t-tests if normally distributed, MannWhitney U test if skewed. Data were analysed using the SAS program [37].

\section{Results \\ Response to HRA-O questionnaire}

The numbers (percentage) of persons returning the HRAO questionnaire were $1090(87.9 \%)$ in London, 804 (91.6\%) in Hamburg, and 748 (85.6\%) in Solothurn. Table 2 compares the characteristics of responders and non-responders to the HRA-O questionnaire. At all sites, persons with fair or poor self-perceived health status were less likely to return the HRA-O questionnaire compared to persons with good or very good self-perceived health status. In Solothurn, this difference was small and statistically non-significant. In London and Hamburg, this difference was larger and statistically significant. In Hamburg, participant age was also related to HRA-O questionnaire response, with older participants having a lower return rate as compared to younger participants. No other characteristics affecting response were identified among the three sites. Overall Pra risk status was similar between responders and non-responders.

\section{Feed-back to the HRA-O questionnaire}

Acceptance of the HRA-O questionnaire was high, with more than $85 \%$ of persons rating comprehension and completion of the questionnaire as easy or very easy. Tables 3 and 4 list the participants' feed-back to the HRAO questionnaire according to participants' age and educational level at the three study sites. As shown in Table 3, a significantly higher proportion of the over 75-year old persons had difficulties with the questionnaire, as compared to younger persons. Similarly, persons with a low level of education had more difficulty comprehending or 


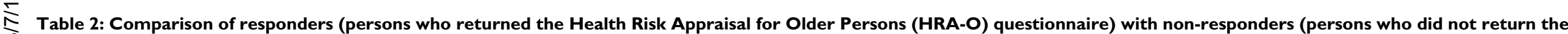
HRA-O questionnaire) at the three study sites

\begin{tabular}{|c|c|c|c|c|c|c|c|c|c|}
\hline \multirow[t]{2}{*}{ Baseline characteristics } & \multicolumn{3}{|c|}{ London (U.K.) } & \multicolumn{3}{|c|}{ Hamburg (Germany) } & \multicolumn{3}{|c|}{ Solothurn (Switzerland) } \\
\hline & Responders & Non-responders & P-value & Responders & Non-responders & P-value & Responders & Non-responders & P-value \\
\hline Age (years) & $74.7 \pm 6.3(1090)$ & $74.8 \pm 6.7(150)$ & 0.70 & $71.5 \pm 7.6(804)$ & $75.5 \pm 7.8(74)$ & 0.002 & $74.5 \pm 5.8(748)$ & $74.4 \pm 6.0(126)$ & 0.87 \\
\hline Female gender & $55.0 \%(599 / 1090)$ & $58.0 \%(87 / 150)$ & 0.71 & $60.9 \%(490 / 804)$ & $67.6 \%(50 / 74)$ & 0.67 & $56.7 \%(424 / 748)$ & $57.9 \%(73 / 126)$ & 0.87 \\
\hline Fair/poor self-perceived health & $23.1 \%(252 / 1090)$ & $34.7 \%(52 / 150)$ & 0.004 & $36.3 \%(292 / 804)$ & $63.5 \%(47 / 74)$ & $<.0001$ & $19.0 \%(142 / 748)$ & $25.4 \%(32 / 126)$ & 0.10 \\
\hline$\geq 1$ hospital admission over past 12 months & $13.6 \%(148 / 1090)$ & $16.7 \%(25 / 150)$ & 0.52 & $21.6 \%(174 / 804)$ & $16.2 \%(12 / 74)$ & 0.09 & $20.5 \%(153 / 748)$ & $16.7 \%(21 / 126)$ & 0.23 \\
\hline$>6$ physician visits over past 12 months & $20.5 \%(223 / 1090)$ & $26.7 \%(40 / 150)$ & 0.16 & $50.1 \%(403 / 804)$ & $47.3 \%(35 / 74)$ & 0.15 & $23.3 \%(174 / 748)$ & $28.6 \%(36 / 126)$ & 0.06 \\
\hline No available caregiver if needed & $17.2 \%(187 / 1090)$ & $20.7 \%(31 / 150)$ & 0.36 & $16.7 \%(134 / 804)$ & $29.7 \%(22 / 74)$ & 0.07 & $10.0 \%(75 / 748)$ & $8.7 \%(11 / 126)$ & 0.53 \\
\hline Pra score & $0.27 \pm 0.11(1090)$ & $0.28 \pm 0.12(150)$ & 0.36 & $0.30 \pm 0.11(804)$ & $0.30 \pm 0.12(74)$ & 0.71 & $0.29 \pm 0.11(748)$ & $0.29 \pm 0.10(126)$ & 0.86 \\
\hline
\end{tabular}

Values are percentages (nominator/denominator) or means \pm standard deviations (denominator).

P-values based on multivariable logistic regression models with covariate pool consisting of the individual Pra items.

Pra score: Probability of repeated admissions; higher scores denote higher risk for hospital admission and other adverse outcomes. for definition see Methods section.

Table 3: Participants' feedback to the HRA-O questionnaire at the three study sites, according to participants' age

\begin{tabular}{|c|c|c|c|c|c|c|}
\hline & \multicolumn{2}{|c|}{ London (U.K.) } & \multicolumn{2}{|c|}{ Hamburg (Germany) } & \multicolumn{2}{|c|}{ Solothurn (Switzerland) } \\
\hline & $<75$ years & $\geq 75$ years & $<75$ years & $\geq 75$ years & $<75$ years & $\geq 75$ years \\
\hline Comprehension of questions/instructions - \% somewhat difficult/very difficult & $5.9 \%(35 / 598)$ & $11.5 \%(55 / 477)^{* *}$ & $4.3 \%(23 / 535)$ & $6.3 \%(16 / 253)$ & $9.2 \%(38 / 4 \mid 2)$ & $17.8 \%(54 / 304)^{* * * *}$ \\
\hline Completion of questionnaire - \% somewhat difficult/very difficult & $5.9 \%(35 / 589)$ & $9.3 \%(43 / 464)^{*}$ & $5.0 \%(25 / 496)$ & $8.0 \%(19 / 237)$ & $7.5 \%(29 / 388)$ & $15.8 \%(44 / 279)^{* * *}$ \\
\hline Use of assistance for completing questionnaire - \% with assistance & $8.6 \%(51 / 593)$ & $\mid 4.6 \%(69 / 47 \mid)^{* *}$ & $5.2 \%(27 / 52 I)$ & $13.1 \%(32 / 245)^{* * *}$ & $16.4 \%(67 / 409)$ & $28.6 \%(88 / 308)^{* * * *}$ \\
\hline Perceived length of questionnaire $-\%$ too long & $30.9 \%(183 / 593)$ & $35.9 \%(169 / 47 I)$ & $28.2 \%(148 / 525)$ & $31.9 \%(76 / 238)$ & $54.7 \%(222 / 406)$ & $58.4 \%(180 / 308)$ \\
\hline Time for completion - min. ( \pm SD) & $42.6 \pm 29.3(589)$ & $56.2 \pm 53.0(464)^{* * * *}$ & $58.8 \pm 27.7(5 \mid 8)$ & $67.6 \pm 31.4(235)^{* * *}$ & $73.1 \pm 39.6(388)$ & $83.2 \pm 48.2(282)^{* *}$ \\
\hline Dislike certain sections of questionnaire $-\%$ agreeing & $4.9 \%(28 / 575)$ & $5.9 \%(27 / 46 I)$ & $9.1 \%(46 / 507)$ & $6.4 \%(14 / 218)$ & II.8\% (44/373) & $13.7 \%(38 / 277)$ \\
\hline Questionnaire should include additional domains - \% agreeing & $19.5 \%(112 / 573)$ & $14.0 \%(60 / 429)^{*}$ & $21.0 \%(102 / 485)$ & $15.9 \%(32 / 201)$ & $5.4 \%(20 / 368)$ & $4.5 \%(12 / 269)$ \\
\hline
\end{tabular}

HRA-O: Health Risk Appraisal for Older Persons

Values are percentages (nominator/denominator) or means \pm standard deviations (denominator).

Denominators vary due to missing individual answers.

* denotes $.0 \mathrm{I}<=\mathrm{P}<.05$; ${ }^{* *}$ denotes $.00 \mathrm{I}<=\mathrm{P}<.0 \mathrm{I}$; *** denotes $\mathrm{P}<.00 \mathrm{I}$; P-values are based on Fisher's exact test (binary variables) and t-test (continuous variables) 
answering the questionnaire as compared to persons with a higher level of education (Table 4). However, even among subgroups reporting greater difficulty in using the questionnaire, the proportion of older persons rating the questionnaire as difficult was less than $20 \%$.

The proportion of persons using assistance for completing the questionnaire ranged from 5 to $31 \%$ percent according to subgroup (age or educational level) and study site. Self-reported time needed for completing the questionnaires varied between study sites and participant age. Persons in Solothurn needed more time to complete the questionnaire compared to persons in London and Hamburg. Those over 75 needed significantly more time to complete the questionnaire compared to younger persons in all sites. Many study participants felt the questionnaire was too long. On the other hand, there was a notable minority of participants suggesting that additional domains should be added to the questionnaire.

\section{Prevalence of identified risks and problems}

Table 5 lists the prevalence of risks and problems identified among study participants at the three study sites. Prevalence rates of identified risks or problems were between 2 and $91 \%$ for the 19 domains covered in the HRA-O. For some risks there were notable differences in prevalence rates between sites (e.g., consumption of high fat food, preventative care use, marginal family ties), indicating that regional factors are associated with risks. Overall, at each site the HRA-O questionnaire revealed relatively high $(>10 \%)$ prevalence rates of most potentially modifiable risk factors for functional decline.

\section{Self-reported reasons for suboptimal health behaviour and preventative care use}

Table 6 lists participants' intention to change health behaviour and self-reported reasons for suboptimal health behaviour or use of preventative services. With regard to physical activity (level of physical activity within the next month or the next 6 months) and nutrition, only a small minority (5.4 percent or less) declare that they plan to change food intake within the next month or the next 6 months. The most frequently reported reason for not changing level of physical activity and nutrition intake is the self-perception of optimal health behaviour despite evidence for suboptimal health behaviour. For example, In London, among 933 persons with a low level of physical activity, $338(36.2 \%)$ reported that they did not increase their level of physical activity because they thought they already exercised frequently and regularly. With regard to tobacco use, this was different. One third to almost one half of persons using tobacco report that they plan to quit within the next month or the next 6 months.

Table 4: Participants' feedback to the HRA-O questionnaire at the three study sites, according to participants' educational level (low vs. medium/high)

\begin{tabular}{|c|c|c|c|c|c|c|}
\hline & \multicolumn{2}{|c|}{ London (U.K.) } & \multicolumn{2}{|c|}{ Hamburg (Germany) } & \multicolumn{2}{|c|}{ Solothurn (Switzerland) } \\
\hline & low & medium/high & low & medium/high & low & medium/high \\
\hline $\begin{array}{l}\text { Comprehension of } \\
\text { questions/instructions - } \\
\% \text { somewhat difficult/very } \\
\text { difficult }\end{array}$ & $8.9 \%(57 / 642)$ & $7.5 \%(32 / 426)$ & $7.9 \%(11 / 140)$ & $3.8 \%(23 / 601)$ & $17.1 \%(54 / 316)$ & $8.8 \%(31 / 352)^{* *}$ \\
\hline $\begin{array}{l}\text { Completion of } \\
\text { questionnaire - \% } \\
\text { somewhat difficult/very } \\
\text { difficult }\end{array}$ & $8.0 \%(50 / 626)$ & $6.4 \%(27 / 420)$ & $8.5 \%(11 / 129)$ & $5.3 \%(30 / 563)$ & $15.4 \%(46 / 299)$ & $7.0 \%(23 / 329)^{* * *}$ \\
\hline $\begin{array}{l}\text { Use of assistance for } \\
\text { completing questionnaire } \\
\text { - \% with assistance }\end{array}$ & $13.1 \%(83 / 636)$ & $8.5 \%(36 / 423)^{*}$ & $17.6 \%(24 / 136)$ & $5.5 \%(32 / 583)^{* * *}$ & $31.4 \%(100 / 318)$ & $\mid 4.5 \%(5 \mathrm{I} / 35 \mathrm{I})^{* * *}$ \\
\hline $\begin{array}{l}\text { Perceived length of } \\
\text { questionnaire }-\% \text { too } \\
\text { long }\end{array}$ & $35.7 \%(227 / 636)$ & $28.7 \%(121 / 421)^{*}$ & $33.3 \%(46 / 138)$ & $27.6 \%(160 / 580)$ & $60.3 \%(190 / 315)$ & $53.0 \%(186 / 351)$ \\
\hline $\begin{array}{l}\text { Time for completion - } \\
\min .( \pm S D)\end{array}$ & $51.3 \pm 46.2(627)$ & $44.6 \pm 34.6(419)^{* *}$ & $65.0 \pm 31.6(131)$ & $60.8 \pm 28.2(576)$ & $78.9 \pm 46.9(297)$ & $75.5 \pm 39.3(330)$ \\
\hline $\begin{array}{l}\text { Dislike certain sections of } \\
\text { questionnaire - \% } \\
\text { agreeing }\end{array}$ & $4.2 \%(26 / 612)$ & $6.8 \%(28 / 4 I I)$ & $9.7 \%(12 / 124)$ & $7.8 \%(44 / 563)$ & I I.5\% (33/286) & $12.9 \%(4|/ 3| 7)$ \\
\hline $\begin{array}{l}\text { Questionnaire should } \\
\text { include additional } \\
\text { domains - \% agreeing }\end{array}$ & $13.4 \%(79 / 591)$ & $22.5 \%(90 / 400) * * *$ & $14.4 \%$ (17/| I8) & $20.7 \%(111 / 535)$ & $\mathrm{I} .8 \%(5 / 28 \mathrm{I})$ & $7.4 \%(23 / 311)^{* *}$ \\
\hline
\end{tabular}

HRA-O: Health Risk Appraisal for Older Persons

Values are percentages (nominator/denominator) or means \pm standard deviations (denominator).

Denominators vary due to missing individual answers.

* denotes $.01<=\mathrm{P}<.05$; ** denotes $.001<=\mathrm{P}<.0 \mathrm{l}$; *** denotes $\mathrm{P}<.00 \mathrm{I}$; $\mathrm{P}$-values are based on Fisher's exact test (binary variables) and t-test (continuous variables). 
Table 5: Prevalence of risks and problems identified with the HRA-O questionnaire at the three study sites

\begin{tabular}{|c|c|c|c|c|}
\hline Domain & Definition of problem/risk & London (U.K.) & Hamburg (Germany) & Solothurn (Switzerland) \\
\hline Accident prevention & Driving without using seat belt & $16.6 \%(174 / 1051)$ & $4.8 \%(37 / 765)$ & $12.7 \%(90 / 707)$ \\
\hline Alcohol use & Possible hazardous alcohol use & $20.4 \%(219 / 1071)$ & $18.8 \%(133 / 706)$ & $14.4 \%(85 / 59 \mid)$ \\
\hline \multirow[t]{2}{*}{ Falls } & $\begin{array}{l}\text { History of repeated falls in previous } 12 \\
\text { months }\end{array}$ & $10.6 \%(111 / 1048)$ & $7.5 \%(58 / 772)$ & $7.2 \%(50 / 691)$ \\
\hline & $\begin{array}{l}\text { Self-reported limitation of activities due } \\
\text { to fear of falling }\end{array}$ & $21.6 \%(230 / 1064)$ & $24.1 \%(189 / 785)$ & $23.5 \%(|67 / 7| I)$ \\
\hline \multirow[t]{4}{*}{ Functional status } & Difficulty in $\geq I$ BADL item & $4.0 \%(43 / 1076)$ & $10.4 \%(82 / 790)$ & $6.4 \%(47 / 730)$ \\
\hline & $\begin{array}{l}\text { Difficulty/need for human assistance in } \\
\geq 2 \text { IADL item }\end{array}$ & $16.7 \%(178 / 1063)$ & $23.2 \%(182 / 785)$ & $19.1 \%(135 / 708)$ \\
\hline & Changed way of doing an activity & $51.9 \%(544 / 1048)$ & $46.7 \%(362 / 775)$ & $51.6 \%(366 / 709)$ \\
\hline & Decreased frequency of activity & $36.8 \%(379 / 1029)$ & $37.5 \%(285 / 760)$ & $37.4 \%(262 / 700)$ \\
\hline Health status & $\begin{array}{l}\text { Moderate or fair self-perceived health } \\
\text { status }\end{array}$ & $22.1 \%(239 / 1080)$ & $29.9 \%(238 / 796)$ & $15.9 \%(116 / 730)$ \\
\hline \multirow[t]{2}{*}{ Hearing } & Impaired hearing & $20.7 \%(206 / 994)$ & $20.4 \%(155 / 759)$ & $28.5 \%(178 / 624)$ \\
\hline & No hearing check-up in previous year & $84.6 \%(908 / 1073)$ & $63.9 \%(508 / 795)$ & $66.2 \%(473 / 715)$ \\
\hline Incontinence & $\begin{array}{l}\text { Urinary incontinence on }>5 \text { days during } \\
\text { the last year }\end{array}$ & $10.7 \%(111 / 1042)$ & $27.2 \%(210 / 772)$ & $20.6 \%(144 / 698)$ \\
\hline \multirow[t]{4}{*}{ Medication use } & Use of $\geq 4$ medications & $34.2 \%(36 I / 1056)$ & $44.3 \%(332 / 749)$ & $30.4 \%(200 / 657)$ \\
\hline & $\begin{array}{l}\text { Use of long-acting benzodiazepine or } \\
\text { amitriptyline }\end{array}$ & $5.6 \%(59 / 1053)$ & $7.6 \%(58 / 768)$ & $7.5 \%(54 / 7 / 9)$ \\
\hline & Medication side effect & $11.9 \%(123 / 1030)$ & $15.1 \%(|| 4 / 755)$ & $9.8 \%(64 / 652)$ \\
\hline & Difficulties with medication compliance & $9.4 \%(90 / 961)$ & $8.0 \%(53 / 660)$ & $5.9 \%(33 / 564)$ \\
\hline Medical History & $\begin{array}{l}\text { Presence of three or more chronic } \\
\text { condition(s) }\end{array}$ & $33.4 \%(354 / 1059)$ & $52.2 \%(396 / 758)$ & $39.5 \%(279 / 707)$ \\
\hline Memory & Memory problems & $10.2 \%(107 / 1053)$ & $5.2 \%(4 \mid / 78 I)$ & $6.6 \%(46 / 701)$ \\
\hline Mood & Depressive mood & $14.3 \%(155 / 1085)$ & $24.1 \%(191 / 792)$ & $14.4 \%(105 / 73 \mid)$ \\
\hline \multirow[t]{5}{*}{ Nutrition } & $\begin{array}{l}\text { Consumption of }>2 \text { high fat food items } \\
\text { per day }\end{array}$ & $76.1 \%(788 / 1035)$ & $35.1 \%(258 / 735)$ & $55.7 \%(354 / 635)$ \\
\hline & $\begin{array}{l}\text { Consumption of }<5 \text { fruit/fibre items per } \\
\text { day }\end{array}$ & $61.1 \%(635 / 1039)$ & $81.2 \%(608 / 749)$ & $74.8 \%(489 / 654)$ \\
\hline & Body mass index $<20$ & $4.8 \%(49 / 1030)$ & $2.3 \%(18 / 787)$ & $2.0 \%(14 / 709)$ \\
\hline & Body mass index $\geq 27$ & $32.9 \%(339 / 1030)$ & $41.0 \%(323 / 787)$ & $52.9 \%(375 / 709)$ \\
\hline & Loss of weight & $3.4 \%(36 / 1069)$ & $4.2 \%(33 / 795)$ & $4.8 \%(35 / 734)$ \\
\hline \multirow[t]{2}{*}{ Oral Health } & Oral health problem & $43.9 \%(463 / 1054)$ & $28.5 \%(224 / 787)$ & $27.1 \%(188 / 694)$ \\
\hline & No dental check in previous year & $25.9 \%(279 / 1077)$ & $17.4 \%(139 / 797)$ & $42.5 \%(306 / 720)$ \\
\hline Physical activity & $\begin{array}{l}\text { Less than } 5 \text { times/week moderate or } \\
\text { strenuous activity }\end{array}$ & $90.7 \%(933 / 1029)$ & $80.1 \%(595 / 743)$ & $88.4 \%(524 / 593)$ \\
\hline \multirow[t]{10}{*}{ Preventative care } & $\begin{array}{l}\text { No blood pressure check in previous } \\
\text { year }\end{array}$ & $17.1 \%(\mid 86 / 1087)$ & $2.5 \%(20 / 792)$ & $4.8 \%(35 / 734)$ \\
\hline & Elevated self-reported blood pressure & $67.5 \%(166 / 246)$ & $61.0 \%(383 / 628)$ & $58.4 \%(26 \mathrm{I} / 447)$ \\
\hline & $\begin{array}{l}\text { No mammography in previous } 2 \text { years } \\
(\text { age }<70)\end{array}$ & $61.0 \%(94 / 154)$ & not available & $70.6 \%(72 / 102)$ \\
\hline & No cervical smear in previous 3 years & $89.7 \%(525 / 585)$ & $36.8 \%(178 / 484)$ & $60.7 \%(244 / 402)$ \\
\hline & $\begin{array}{l}\text { No cholesterol measurement in } \\
\text { previous } 5 \text { years }(\text { age }<75)\end{array}$ & $43.2 \%(26 I / 604)$ & $6.0 \%(32 / 534)$ & $24.9 \%(99 / 397)$ \\
\hline & $\begin{array}{l}\text { Elevated self-reported cholesterol (age } \\
<75)\end{array}$ & $8.7 \%(8 / 92)$ & $40.3 \%(94 / 233)$ & $15.2 \%(5 / 33)$ \\
\hline & $\begin{array}{l}\text { No faecal occult blood test in previous } \\
\text { year (age }<80)\end{array}$ & $93.0 \%(796 / 856)$ & $35.0 \%(233 / 665)$ & $68.5 \%(395 / 577)$ \\
\hline & $\begin{array}{l}\text { No blood glucose measurement in } \\
\text { previous } 3 \text { years }\end{array}$ & $78.7 \%(852 / 1082)$ & $10.8 \%(85 / 784)$ & $24.7 \%(172 / 695)$ \\
\hline & $\begin{array}{l}\text { No influenza vaccination in previous } \\
\text { year }\end{array}$ & $18.2 \%(198 / 1087)$ & $40.7 \%(323 / 794)$ & $53.9 \%(395 / 733)$ \\
\hline & No pneumococcal vaccination (ever) & $78.8 \%(853 / 1083)$ & $89.7 \%(703 / 784)$ & $91.3 \%(639 / 700)$ \\
\hline Pain & Presence of moderate to severe pain & $27.9 \%(291 / 1044)$ & $37.0 \%(282 / 762)$ & $24.9 \%(166 / 667)$ \\
\hline \multirow[t]{5}{*}{ Social factors } & Low level of emotional support & $10.6 \%(114 / 1076)$ & $8.8 \%(69 / 784)$ & $9.4 \%(64 / 68 I)$ \\
\hline & High risk of social isolation & $14.1 \%(152 / 1076)$ & $19.1 \%(150 / 784)$ & $9.7 \%(66 / 681)$ \\
\hline & Marginal family ties & $14.4 \%(155 / 1076)$ & $18.1 \%(142 / 784)$ & $6.6 \%(45 / 68 I)$ \\
\hline & Marginal friendship ties & $17.9 \%(193 / 1076)$ & $20.8 \%(163 / 784)$ & $18.5 \%(126 / 68 I)$ \\
\hline & No participation in groups & $32.2 \%(347 / 1077)$ & $37.9 \%(30 \mathrm{I} / 795)$ & $20.9 \%(149 / 7 \mid 3)$ \\
\hline Tobacco use & Current tobacco use & $11.2 \%(|| 4 / 102 \mid)$ & $13.1 \%(97 / 739)$ & $13.3 \%(86 / 645)$ \\
\hline \multirow[t]{2}{*}{ Vision } & Problem in $\geq$ I vision sub-domain & $16.5 \%(169 / 1026)$ & $16.2 \%(125 / 770)$ & $13.7 \%(93 / 681)$ \\
\hline & No vision check-up in previous year & $34.1 \%(369 / 1081)$ & $28.3 \%(225 / 795)$ & $38.3 \%(280 / 732)$ \\
\hline
\end{tabular}

HRA-O: Health Risk Appraisal for Older Persons

Values are percentages (nominator/denominator).

Denominators vary due to missing individual answers.

For definition of variables, see Table 1 . 
Table 6: Intention to change health behaviour and self-reported reasons for not changing health behaviour/preventative care use identified with the HRA-O questionnaire at the three study sites

\begin{tabular}{|c|c|c|c|c|}
\hline Category & $\begin{array}{l}\text { Self reported answer } \\
\text { category }\end{array}$ & London (U.K.) & Hamburg (Germany) & $\begin{array}{l}\text { Solothurn } \\
\text { (Switzerland) }\end{array}$ \\
\hline \multirow[t]{2}{*}{$\begin{array}{l}\text { Intention to increase } \\
\text { physical activity }\end{array}$} & $\begin{array}{l}\text { Plans to take steps in next } \\
\text { month }\end{array}$ & $2.5 \%(2 \mathrm{I} / 853)$ & $1.0 \%(5 / 507)$ & $1.6 \%(7 / 426)$ \\
\hline & $\begin{array}{l}\text { Plans to take steps in the } \\
\text { next } 6 \text { months }\end{array}$ & $2.9 \%(25 / 853)$ & $0.6 \%(3 / 507)$ & $0.2 \%(1 / 426)$ \\
\hline \multirow[t]{7}{*}{$\begin{array}{l}\text { Reasons for not increasing } \\
\text { physical acitivity }\end{array}$} & $\begin{array}{l}\text { I already exercise } \\
\text { frequently and regularly }\end{array}$ & $36.2 \%(338 / 933)$ & $47.7 \%(284 / 595)$ & $63.2 \%(331 / 524)$ \\
\hline & I have a physical limitation & $22.0 \%(205 / 933)$ & $14.3 \%(85 / 595)$ & $6.7 \%(35 / 524)$ \\
\hline & $\begin{array}{c}\text { I don't have time/don't get } \\
\text { around it }\end{array}$ & $18.8 \%(175 / 933)$ & $6.1 \%(36 / 595)$ & $3.8 \%(20 / 524)$ \\
\hline & $\begin{array}{l}\text { I have pain with physical } \\
\text { activity }\end{array}$ & $18.0 \%(168 / 933)$ & $25.7 \%(153 / 595)$ & $16.8 \%(88 / 524)$ \\
\hline & $\begin{array}{l}\text { I have an illness limiting my } \\
\text { physical activity }\end{array}$ & $11.5 \%(107 / 933)$ & $25.9 \%(154 / 595)$ & $13.2 \%(69 / 524)$ \\
\hline & $\begin{array}{l}\text { I don't have anyone to } \\
\text { exercise with }\end{array}$ & $5.8 \%(54 / 933)$ & $8.4 \%(50 / 595)$ & $4.4 \%(23 / 524)$ \\
\hline & $\begin{array}{l}\text { There is nowhere to } \\
\text { exercise }\end{array}$ & $1.9 \%(18 / 933)$ & $8.7 \%(52 / 595)$ & $4.8 \%(25 / 524)$ \\
\hline \multirow[t]{2}{*}{$\begin{array}{l}\text { Intention to decrease high } \\
\text { fat intake }\end{array}$} & $\begin{array}{l}\text { Plans to take steps in next } \\
\text { month }\end{array}$ & $2.1 \%(16 / 765)$ & $2.8 \%(7 / 253)$ & $0.9 \%(3 / 333)$ \\
\hline & $\begin{array}{l}\text { Plans to take steps in the } \\
\text { next } 6 \text { months }\end{array}$ & $1.6 \%(12 / 765)$ & $0.8 \%(2 / 253)$ & $0.9 \%(3 / 333)$ \\
\hline \multirow[t]{4}{*}{$\begin{array}{l}\text { Reason for not decreasing } \\
\text { high fat intake }\end{array}$} & $\begin{array}{l}\text { I already minimise fat } \\
\text { intake }\end{array}$ & $75.4 \%(594 / 788)$ & $70.9 \%(183 / 258)$ & $67.5 \%(239 / 354)$ \\
\hline & $\begin{array}{l}\text { I like the taste of high-fat } \\
\text { foods }\end{array}$ & $19.5 \%(154 / 788)$ & $19.4 \%(50 / 258)$ & $9.3 \%(33 / 354)$ \\
\hline & $\begin{array}{c}\text { I don't think it's important } \\
\text { to eat less fat }\end{array}$ & $5.3 \%(42 / 788)$ & $11.6 \%(30 / 258)$ & $13.6 \%(48 / 354)$ \\
\hline & $\begin{array}{l}\text { Trouble to shop/prepare } \\
\text { low-fat foods }\end{array}$ & $2.4 \%(19 / 788)$ & $5.4 \%(14 / 258)$ & $7.6 \%(27 / 354)$ \\
\hline \multirow[t]{2}{*}{$\begin{array}{l}\text { Intention to increase fruit/ } \\
\text { fibre intake }\end{array}$} & $\begin{array}{l}\text { Plans to take steps in next } \\
\text { month }\end{array}$ & $0.8 \%(5 / 623)$ & $0.7 \%(4 / 596)$ & $0.2 \%(1 / 470)$ \\
\hline & $\begin{array}{l}\text { Plans to take steps in the } \\
\text { next } 6 \text { months }\end{array}$ & $1.0 \%(6 / 623)$ & $0.2 \%(1 / 596)$ & $0.2 \%(1 / 470)$ \\
\hline $\begin{array}{l}\text { Reason for not increasing } \\
\text { low fruit/fibre intake }\end{array}$ & $\begin{array}{l}\text { I already eat plenty of } \\
\text { fruits/vegetables }\end{array}$ & $87.9 \%(558 / 635)$ & $91.0 \%(553 / 608)$ & $93.7 \%(458 / 489)$ \\
\hline \multirow[t]{2}{*}{$\begin{array}{l}\text { Intention to change current } \\
\text { tobacco use }\end{array}$} & $\begin{array}{l}\text { Plans to quit smoking in } \\
\text { next month }\end{array}$ & $16.7 \%(14 / 84)$ & $16.0 \%(12 / 75)$ & $22.6 \%(12 / 53)$ \\
\hline & $\begin{array}{l}\text { Plans to quit smoking in } \\
\text { next } 6 \text { months }\end{array}$ & $28.6 \%(24 / 84)$ & $17.3 \%(13 / 75)$ & $18.9 \%(10 / 53)$ \\
\hline \multirow[t]{4}{*}{$\begin{array}{l}\text { Reason for not using } \\
\text { preventative services }\end{array}$} & $\begin{array}{l}\text { My general practitioner } \\
\text { never recommended it }\end{array}$ & $50.5 \%(548 / 1086)$ & $22.2 \%(173 / 778)$ & $16.0 \%(|17 / 73|)$ \\
\hline & I've never thought about it & $21.5 \%(234 / 1086)$ & $12.3 \%(96 / 778)$ & $10.9 \%(80 / 731)$ \\
\hline & $\begin{array}{l}\text { I have no need to; I have no } \\
\text { health problems }\end{array}$ & $17.5 \%(190 / 1086)$ & $17.0 \%(132 / 778)$ & $20.2 \%(|48 / 73|)$ \\
\hline & $\begin{array}{l}\text { I have already had these } \\
\text { preventative services }\end{array}$ & $15.7 \%(171 / 1086)$ & $37.1 \%(289 / 778)$ & $39.8 \%(29|/ 73|)$ \\
\hline
\end{tabular}

HRA-O: Health Risk Appraisal for Older Persons, values are percentages (nominator/denominator).

Denominators are persons at risk for the selected health behaviour or preventative care use (e.g., intention to decrease high fat intake among persons with high fat intake, as defined in Table 5). Answers are for predefined categories. Multiple answer were allowed for reasons of sub-optimal health behaviour; only reasons given by $\geq 5 \%$ of persons in at least one study site are listed, and listed according to the rank order in London. 
The self-reported reasons for not using all preventative care services recommended to older persons varied by site. In London, more than $50 \%$ of the participants stated that their general practitioner had never recommended it. In Solothurn and Hamburg, the most frequently given reason was "I have already had these preventative services." Other reasons, such as cost or lack of time were given by less than 5 percent of participants at all sites.

\section{Discussion}

To our knowledge this is the first HRA instrument for use in older persons that has been developed and evaluated outside North America for international use. Base-line data from its use in the PRO-AGE multi-centre trial confirm that the HRA-O questionnaire is feasible in this population, including those at advanced age and with lower educational levels. In addition, the HRA-O questionnaire identifies a large number of potentially modifiable risks for functional decline and related problems. Participants' intention to change, and self-reported reasons for not changing health behaviour suggested that for some risk factors participants were in a pre-contemplation phase [27], having no short- or medium-term plans for changing health behaviour, and many perceived their health behaviour or preventative care uptake as optimal, despite indications of deficits according to the HRA-O based evaluation.

There are some limitations. This study might overestimate the response rate to the HRA-O questionnaire because only those participants who had given informed consent to participate in the study were sent the HRA-O questionnaire. This limitation cannot be avoided in the context of a controlled trial. Despite this limitation, the response rate of $>80 \%$ for a multidimensional questionnaire, without a reminder system, is remarkable and underlines its practicability. One likely explanation of the high response rate was the contribution of the general practitioner's relationship with his/her patients.

Second, although acceptability of the instrument would certainly differ in populations with a very low level of education (in this project, most persons classified as having a low level of education had had 9 years of education), it is likely that the instrument can be used at other sites as well. The three study sites represented here include urban and rural regions, different languages, different health care systems, and persons with a broad range of socioeconomic characteristics.

Third, the prevalence rates found in this study may not be representative of the population of community-dwelling older persons in these regions. Participants were selected according to practice registration and eligibility criteria, and persons not interested in participating in the study were excluded. Nevertheless, comparison of participant characteristics with available national data reveals similarities, suggesting that findings of this study give appropriate estimates for non-disabled non-institutionalised older persons.

\section{Conclusion}

This study has implications for practice and research. HRA-O has multiple advantages, compared with other HRA tools for older persons. For one, the present HRA-O shares the distinguishing features of HRA-E, as described earlier. In addition, this study gave evidence that HRA-O has additional unique benefits: HRA-O has high acceptance rates and good feasibility in community-dwelling older persons at different sites, and HRA-O has proven to be functional in a multilingual mode.

At the present time, many intervention programs addressing health promotion and prevention have used alternative strategies requiring a large amount of professional time without a self-administered component. For example, most programs of preventive home visits start with an approximately two-hour multidimensional evaluation of older persons by a health professional [38]. Other programs use a self-administered survey approach, but are limited to a brief questionnaire focussing on general aspects of health risks and do not address all potential risk domains with domain-specific screening instruments [1].

There is potential for further development. First, with additional data and analyses from the PRO-AGE study, a further update of the HRA-O is currently under way. Second, in the UK, the Department of Health is currently funding a study to identify social aspects that could be added to HRA-O [39]. Third, in the future, it might be possible to give quantitative estimates of individual risks for functional decline, and the potential impact of risk factor modification. The HRA-O instrument combined with specific interventions might be a promising tool for individualised health promotion and prevention programs in older persons.

\section{Competing interests}

The author(s) declare that they have no competing interests.

\section{Authors' contributions}

All authors are members of the PRO-AGE project group and participated in the conceptualisation and implementation of the study. HM and UD were the administrative coordinators of PRO-AGE project, AS was the technical/ scientific coordinator of the project. AS, JB, CS, and HM developed the study plan. KK, DH, SI, CS implemented the London (U.K.) trial; UD, JA, WR, HM implemented the Hamburg (Germany) trial; AS was responsible for the 
implementation of the study in Solothurn (Switzerland). GG, ME, KI, and AS performed the central data management and data analysis. JH and JB was responsible for HRA-O development in the United States. JB was involved as senior consultant to the project, and contributed to the trial design, data analysis, and data interpretation. AS and KK developed the first version of this manuscript. All authors contributed to the present manuscript.

\section{Additional material}

\section{Additional File 1}

Older Persons Health Profile Questionnaire, version 2000, U.K. English version. Health Risk Appraisal (HRA-O) Questionnaire U.K. (non-printable PDF document, 34 pages).

Click here for file

[http://www.biomedcentral.com/content/supplementary/1471-

2288-7-1-S1.pdf]

\section{Acknowledgements}

The PRO-AGE project was supported by grants of the European Union (QLK6-CT-1999-02205), the Federal Education and Science Ministry (Bern, Switzerland, BBW 9903 II.I), the Swiss National Science Foundation (3252804.97), the Swiss Foundation for Health Promotion (Project No. 398), and the Velux Foundation. The intervention program in Hamburg was supported by the Bundesministerium für Familie, Senioren, Frauen und Jugend and the Max und Ingeburg Herz Foundation (group sessions) and by the Robert Bosch Stiftung (preventive home visits). John C. Beck was supported with a grant of the Langley Research Foundation, Los Angeles. HRAE was developed by a group of University of California faculty (see reference No.2). The subsequent development and field testing of HRA-O was coordinated by the Bern research group. We are grateful to the practitioners and participants involved in this study.

London: Administrative and clinical staff at the Elliott Hall Medical Centre, The Ridgeway Surgery, Paxton Green Group Practice and The Forest Hill Group Practice for their commitment to and sustained involvement in this project.

Hamburg: Susann Laub (Research department at the Albertinen-Haus Hamburg): Scientific nurse for the recruitment process and data collection. Norbert Lübke (Kompetenz Centrum Geriatrie Hamburg): Geriatrician for the training of General Physicians (Quality Circle) and adaptation of the evidence based training manual to the German national health care system.

Solothurn (Switzerland) and PRO-AGE scientific project coordination: Christoph Minder contributed to the original proposal and analytic plan. Stephan Born was responsible for study coordination in Europe and for data management. Andreas Lack, Thomas Münzer and Stefan Goetz contributed to the development and implementation of the intervention programme in Solothurn. Jim Gabriel implemented the software program changes.

The members of the Expert Panel were (in alphabetical order) Prof. Margret M. Baltes, Stanford, U.S.A. (deceased); Prof. John C. Beck, Los Angeles, U.S.A.; Dr. Dorly Deeg, Amsterdam, Netherlands; Dr. Stefan Goetz, Bern, Switzerland; Dr. Steve lliffe, London, U.K.; Prof. C. Lucke, Langenhagen Germany; Prof. Hans Peter Meier-Baumgartner, Hamburg Germany; Prof.
Thorsten Nikolaus, Ulm, Germany; Prof. Marianne Schroll, Copenhagen, Denmark; Prof. Cameron G. Swift, London, U.K.; Prof. Heather Young, Seattle, U.S.A. and was supported by a grant from the Robert Bosch Foundation, Stuttgart, Germany. Additional international members of the PROAGE study group were: Dr. Carsten Hendriksen and Dr. Mikkel Vass, Copenhagen, Denmark; Dr. Brenda Penninx and Dr. Hein von Hout, Amsterdam, The Netherlands; Primaria Dr. Katharina Pils and Ilse Howanietz, Vienna, Austria.

\section{References}

I. Rand Corporation: Health Risk Appraisals and Medicare. Evidence report and evidence-based recommendations. 2000 [http://www.rand.org/cgi-bin/health/ showab.cgi?key $=2003$ 406\&year $=2003$ ]. US Department of Health and Human Services. Baltimore MD

2. Breslow L, Beck JC, Morgenstern H, Fielding JE, Moore AA, Carmel $M$, Higa J: Development of a health risk appraisal for the elderly (HRA-E). Am J Health Promot 1997, I I:337-343.

3. Stuck $A E$, Kharicha $K$, Dapp $U$, Anders J, Von Renteln-Kruse W, Meier-Baumgartner HP, Iliffe S, Harari D, Bachmann MD, Egger M, Gillmann G, Beck JC, Swift CG: The PRO-AGE study: An international randomised controlled study of health risk appraisal for older persons based in general practice. BMC Med Res Methodol 2007, 7(I):2.

4. Stuck AE, Walthert J, Nikolaus T, Büla CJ, Hohmann C, Beck JC: Risk factors for functional status decline in community-dwelling elderly people: a systematic literature review. Soc Sci Med 1999, 48:445-469.

5. Peter-Wüest I, Stuck AE, Dapp U, Nikolaus T, Goetz SM, Gillmann G, Beck JC: A new multidimensional instrument for preventive in-home assessments in older people: results of a pilot test. Z Gerontol Geriat 2000, 33:44-5I.

6. Goetz SM, Stuck AE, Hirschi A, Gillmann G, Dapp U, Nikolaus T Minder CE, Beck JC: Test-retest reliability of a newly developed German language instrument for multidimensional geriatric assessment. Z Geront Geriat 200 I, 34: I96-206.

7. Goetz SM, Stuck AE, Hirschi A, Gillmann G, Dapp U, Minder CE, Beck JC: A new multidimensional assessment instrument in German for prevention in older persons: Comparison of the selfadministered with the interviewer-administered version. $Z$ Soz.-Präventivmedizin 2000, 45: 134-146.

8. Stuck AE, Elkuch P, Dapp U, Anders J, lliffe S, Swift CG: Feasibility and yield of a self-administered questionnaire for health risk appraisal in older people in three European countries. Age Ageing 2002, $31: 463-467$.

9. Iliffe $S$, Kharicha K, Harari D, Swift C, Stuck AE: Health risk appraisal for older people in general practice using an expert system: a pilot study. Health \& Social Care in the Community 2005, 13:21-29.

10. Ludwig R: Preventive health care use in older people in Switzerland. Thesis, University of Bern 2002.

II. Atchison KA, Dolan TA: Development of the Geriatric Oral Health Assessment Index. J Dent Educ 1990, 54(I I):680-7.

12. Ferrell BA, Stein WM, Beck JB: The Geriatric Pain Measure: Validity, reliability and factor analysis. J Am Geriatr Soc 2000 , 48:1669-1673.

13. Fried LP, Bandeen-Roche K, Chaves PH, Johnson BA: Preclinical mobility disability predicts incident mobility disability in older women. J Gerontol A Biol Sci Med Sci 2000, 55(1):M43-M52.

14. Beers $M H$ : Explicit criteria for determining potentially inappropriate medication use by the elderly. Arch Intern Med 1997, 157:1531-1536.

15. Babor TF, de la Fuente JR, Saunders J, Grant M: AUDIT - The Alcohol Use Disorders Identification Test: guidelines for use in primary health care. Geneva: World Health Organization; 1992.

16. Berkman LF, Syme SL: Social networks, host resistance, and mortality: A nine-year follow-up study of Alameda County residents. Am J Epidemiol 1979, 109: 186-204.

17. Diokno AC, Brock BM, Brown MB, Herzog AR: Prevalence of urinary incontinence and other urological symptoms in the noninstitutionalized elderly. J Urol 1986, 136:1022-1025.

18. Human Population Laboratory: Health and Ways of Living. Human Population Laboratory (HPL), Men's Form 1965. 
19. Katz S, Ford AB, Moskowitz RW, Jackson BA, Jaffe MW: Studies of illness in the aged. The index of ADL: A standardized measure of biological and psychosocial function. JAMA 1963, 185:9|4-919.

20. Kelsey JL, Browner WS, Seeley DG, Nevitt MC, Cummings SR: Risk factors for fractures of the distal forearm and proximal humerus. Am J Epidemiol 1992, 135:477-89.

21. Kreuter MW, Strecher VJ: Changing inaccurate perceptions of health risk: Results from a randomized trial. Health Psychol 1995, 14:56-63.

22. Lawton MP, Brody EM: Assessment of older people: Self-maintaining instrumental activities of daily living. Gerontologist 1969, 9:179-186.

23. Lichtenstein MJ, Bess FH, Logan SA: Validation of screening tools for identifying hearing-impaired elderly in primary care. JAMA 1988, 259:2875-2878.

24. Lubben JE: Assessing social networks among elderly populations. Fam Comm Health 1988, I I:42-52.

25. Mangione CM, Lee PP, Pitts J, Gutierrez P, Berry S, Hays RD: Psychometric properties of the National Eye Institute Visual Function Questionnaire (NEI-VFQ). Arch Ophthalmol 1998, I 16:1496-504.

26. National Center for Chronic Disease Prevention and Health Promotion: Behavioral Risk Factor Survey. Department of Health and Human Services; 1993.

27. Prochaska JO, DiClemente CC, Norcoss JC: In search of how people change: applications to addictive behaviours. Am Psychol 1992, 47: I I02-III4.

28. Riege WH: Self-report and tests of memory aging. Clin Gerontol 1982, I:23-36.

29. Sherbourne $C D$, Stewart AL: The MOS social support survey. Soc Sci Med I 99I, 32:705-7I4.

30. Stewart AL, Hays RD, Ware JE: The MOS short-form general health survey. Reliability and validity in a patient population. Med Care 1988, 26:724-732.

31. Stoy DB, Curtis RC, Dameworth KS, Dowdy AA, Hegland J, Levin JA, Sousoulas BG: The successful recruitment of elderly black subjects in a clinical trial: the CRISP experience. Cholesterol Reduction in Seniors Program. J Natl Med Assoc 1995, 87:280-287.

32. Tinetti ME, Speechley M, Ginter SF: Risk factors for falls among elderly persons living in the community. N Engl ] Med 1988, 319:170I-1707.

33. US Preventive Health Services Task Force: Guide to clinical preventive services. 2nd edition. Baltimore, MD: Williams \& Wilkins; 1996.

34. Washburn RA, Smith KW, Jette AM, Janney CA: The Physical Activity Scale for the Elderly (PASE): development and evaluation. J Clin Epidemiol 1993, 46: 153-162.

35. Wasson J, Nierenberg D, Landgraf J: The effect of a patient questionnaire on drug-related symptoms in elderly outpatients. Ann Rev Geriatr \& Gerontol 1992, I 2: 109-1 25.

36. Boult C, Dowd B, McCaffrey D, Boult L, Hernandez R, Krulewitch H: Screening elders for risk of hospital admission. J Am Geriatr Soc 1993, 41:8II-817.

37. SAS Institute Inc: SAS/STAT ${ }^{\circledR}$ 9.I User's Guide. Cary, NC: SAS Institute Inc; 2004.

38. Stuck AE, Egger M, Hammer A, Minder CE, Beck JC: Home visits to prevent nursing home admission and functional decline in elderly people: Systematic review and meta-regression analysis. JAMA 2002, 287: 1022-1028.

39. Iliffe S, Kharicha K, Goodman C, Harari D, Swift C, Manthorpe J: Smarter working in primary care. Quality in Ageing 2005, 6:4-I I.

\section{Pre-publication history}

The pre-publication history for this paper can be accessed here:

http://www.biomedcentral.com/1471-2288/7/1/prepub
Publish with Bio Med Central and every scientist can read your work free of charge

"BioMed Central will be the most significant development for disseminating the results of biomedical research in our lifetime. "

Sir Paul Nurse, Cancer Research UK

Your research papers will be:

- available free of charge to the entire biomedical community

- peer reviewed and published immediately upon acceptance

- cited in PubMed and archived on PubMed Central

- yours - you keep the copyright
BioMedcentral 